\title{
PENGEMBANGAN PRODUK INDIKASI GEOGRAFIS DALAM KONTEKS SHARING ECONOMY DI ERA DISRUPSI DIGITAL
}

\section{RANTI FAUZA MAYANA*)}

Fakultas Hukum Universitas Padjadjaran (UNPAD), Jalan Raya Bandung Sumedang KM. 21 Hegarmanah Jatinangor Sumedang, Email : ranti fauza@yahoo.com.

\section{TISNI SANTIKA}

Fakultas Hukum Universitas Pasundan (UNPAS), Jalan Lengkong Besar No. 68 Bandung, Email : tisnisantika@unpas.ac.íd.

\begin{abstract}
Abstrak
Merupakan suatu ironi bahwa Indonesia sebagai salah satu negara kepulauan terbesar dengan kondisi alam yang unik dan beragam serta memiliki potensi besar untuk mengembangkan produk berkualitas tinggi yang dikombinasikan dengan kreativitas serta faktor sosial dan budaya, hingga saat ini masih berjuang keras untuk membentuk kerangka ekonomi berbasis kreativitas dan kolektivitas lokal sebagai pilar ekonomi kerakyatan yang menghasilkan keuntungan signifikan. Terkait dengan fakta tersebut, penelitian ini menganalisis pemanfaatan Indikasi Geografis sebagai bagian dari kekayaan intelektual yang merupakan sebuah rezim perlindungan produk yang berakar pada lokalitas namun telah secara luas diterima dalam skala internasional. Hasil penelitian menunjukkan bahwa produk Indikasi Geografis memiliki korelasi sangat kuat dengan pembangunan kemandirian ekonomi lokal dan memiliki potensi untuk berperan sebagai instrumen trickle - down effect sekaligus bottom up economic development dalam kerangka sharing economy. Lebih jauh, era disrupsi digital menawarkan platform pengembangan dan promosi produk, penciptaan kolaborasi ekonomi yang efektif sebagai sumber pendapatan, membuka lapangan pekerjaan, pengentasan kemiskinan, peningkatan taraf hidup dan pemberdayaan masyarakat.

Kata Kunci: Indikasi Geografis, Sharing Economy, Disrupsi Digital.
\end{abstract}

\begin{abstract}
It is such an irony that Indonesia, as one of the biggest archipelagic countries blessed with unique and vary geographical conditions along with great potential to develop high quality product combined with creativity, social and cultural factors, remains in struggle to formulate and develop local creativity and collectivity as the people's economy pillars with significant benefits. In accordance with those facts, this research aimed to provide critical conceptual ideas for Geographical Indications utilization as the part of intellectual property rooted from locality but has been internationally accepted. The findings showed that Geographical Indication products posses utter potential to play the determinant role in creating trickle-down effect and bottom-up economic development instrument through the sharing of economic framework. Furthermore, digital disruption era offers an effective platform for product development and promotion in a collaborative space in generating income, creating job vacancy, poverty elevation, community empowerment and development. Keywords: Geographical Indications, Sharing Economy, Digital Disruption.
\end{abstract}




\section{PENDAHULUAN}

Theodore Roszak, Professor Emeritus sejarah di California State University menyatakan bahwa setiap periode sejarah selalu memiliki ciri atau identitasnya masing - masing yang dinamakannya dengan istilah "the spirit of the times" (Roszak 1969). Dunia telah mengalami periode dengan ciri khas masing - masing mulai dari age of faith pada abad pertengahan, era ilmu pengetahuan (age of reason), era penemuan (age of discovery), era kreativitas (age of creativity) dan kini dunia telah berada pada era teknologi (age of technology). Age of creativity dan age of technology terutama teknologi informasi telah memunculkan ekonomi kreatif sebagai sebuah tendensi dan preferensi dalam perekonomian global. Di era ekonomi berbasis kreativitas, terjadi pula pergeseran model ekonomi dari model owning economy ke arah sharing economy yang dipandang lebih efektif dalam pemanfaatan sumber daya ekonomi dengan keuntungan yang mendukung upaya pemerataan ekonomi dan kesejahteraan sosial (social welfare / shared prosperity).

Model owning economy yang identik dengan pemilikan privat (baik perorangan, badan usaha maupun badan hukum) dimana kepemilikan modal, proses produksi, investasi dilakukan sendiri oleh pelaku usaha sehingga keuntunganpun akan dinikmati sendiri oleh pelaku usaha tersebut dinilai tidak mampu melakukan optimalisasi pemanfaatan sumber daya ekonomi (economic capital utility) dan distribusi pendapatan secara merata menuju kesejahteraan sosial karena cenderung mendorong konglomerasi yang malah mengakibatkan kesenjangan ekonomi semakin melebar. Sebaliknya, konsep sharing economy yang mulai mengemuka sejak tahun 2009 (Demary 2015) memiliki banyak keunggulan kompetitif (Horton and Zeckhauser 2016) sebagai suatu model ekonomi yang bekerja melalui proses kolaborasi aset, ide dan kreativitas dari sekumpulan orang dengan efektif dan efisien serta dapat memitigasi pengelolaan risiko dalam penciptaan dan pemasaran produk dalam menghasilkan pendapatan (generate income) yang kemudian akan didistribusikan kembali kepada para kolaborator 
dalam sebuah collaborative platform sehingga dikenal juga sebagai model Collaborative Economy (Athanassiou and Kotsi 2019).

Di era ekonomi kreatif dan disrupsi digital, konsep modal bergeser dari dominasi fixed asset capital menuju intangible asset dan intellectual capital, hal ini semakin memunculkan peran dan potensi kekayaan intelektual sebagai suatu aset potensial dalam kegiatan ekonomi. Kekayaan Intelektual (Intellectual Property Rights - selanjutnya disebut KI) adalah hak yang timbul atau lahir karena kemampuan intelektual manusia (Damian 2014). Secara umum KI merupakan hak untuk menikmati hasil kreativitas manusia secara ekonomis (Sudaryat and Permata 2010). Berdasarkan klasifikasi TRIPs Agreement yang merupakan kesepakatan negara - negara anggota World Trade Organization (WTO) yang paling komprehensif di bidang Kekayaan Intelektual dan telah diratifikasi oleh Indonesia melalui Undang - Undang Nomor 7 Tahun 1994 tentang Pengesahan Agreement Establishing The World Trade Organization (Persetujuan Pembentukan Organisasi Perdagangan Dunia), lingkup KI terdiri dari Hak Cipta dan Hak Terkait serta Hak Kekayaan Industri yang terdiri Paten, Desain Industri, Merek, Indikasi Geografis, Rahasia Dagang, Desain Tata Letak Sirkuit Terpadu dan Varietas Tanaman.

Sebagai suatu bentuk hak milik (property right) yang timbul dari sistem hukum barat mengenai hak kepemilikan individu. Di Indonesia konsep kepemilikan $\mathrm{KI}$ secara umum didasarkan pada hak kebendaan sebagaimana diatur dalam Buku II KUHPerdata dimana kekayaan intelektual digolongkan sebagai benda bergerak yang tidak berwujud yang dimiliki oleh subjek hukum sebagai sebuah kekuatan yang dapat dipergunakan untuk memperkaya kehidupan seseorang dan masa depan suatu bangsa secara material, budaya dan sosial (Alfons 2017). Sebagai suatu hak milik, KI memiliki fungsi sosial meskipun merupakan suatu hak yang sifatnya eksklusif, namun apabila kita melihat secara khusus pada serangkaian undang undang di bidang $\mathrm{KI}$, terdapat corak kolektivitas yang cukup kental terkandung dalam rezim Indikasi Geografis (IG) yang merupakan "suatu tanda yang menunjukkan daerah asal suatu barang dan / atau produk yang karena faktor 
lingkungan geografis termasuk faktor alam, faktor manusia atau kombinasi dari kedua faktor tersebut memberikan reputasi, kualitas dan karaktertistik tertentu pada barang dan / atau produk yang dihasilkan (Indonesia, n.d.)

Konvensi Paris secara eksplisit mengakomodir hak kepemilikan komunal masyarakat terhadap IG dengan menetapkan pihak terkait sebagai subjek pemegang hak atas IG, dimana pemegang hak didefinisikan secara luas mulai dari produsen, pabrikan baik itu individu maupun badan hukum yang terkait dengan proses produksi, distribusi dan perdagangan produk IG baik dalam lingkup lokal, regional maupun nasional. Berdasarkan pada cakupan yang luas ini, perlindungan IG pada hakikatnya merupakan perlindungan bagi produsen, konsumen dan masyarakat pada umumnya (WIPO 1883).

IG telah menjadi sebuah rezim perlindungan produk yang berakar pada lokalitas namun telah diterima dalam skala internasional sebagai suatu aspek esensial dalam pemasaran produk. IG merupakan rezim KI dengan elemen kolektivitas yang sangat potensial untuk dapat berperan sebagai katalisator dalam sharing economy di Indonesia. Pasal 53 ayat (3) Undang - Undang Nomor 20 Tahun 2016 Tentang Merek dan Indikasi Geografis mengakomodir konsep pemilikan komunal dalam IG ke dalam ranah praktikal yang menyatakan bahwa Pemohon dalam pendaftaran IG merupakan lembaga yang mewakili masyarakat di kawasan geografis tertentu yang mengusahakan suatu barang dan / atau produk berupa Sumber Daya Alam (SDA), barang kerajinan tangan, hasil industri dan / atau Pemerintah Daerah Provinsi atau Kabupaten / Kota.

Dalam penjelasan Pasal 53 ayat (3) huruf a Undang - Undang Nomor 20 Tahun 2016 Tentang Merek dan Indikasi Geografis dinyatakan bahwa lembaga yang mewakili masyarakat di kawasan geografis tertentu antara lain asosiasi produsen, koperasi dan Masyarakat Perlindungan Indikasi Geografis (MPIG). Penegasan mengenai kepemilikan kolektif terkandung dalam rumusan para pemegang hak IG yang sah didefinisikan sebagai semua pihak / pelaku di komunitas yang berkontribusi pada rantai nilai dari barang dan / atau produk IG dan semua 
pihak yang terus memproduksi dan menghasilkan produk dengan reputasi barang dan / atau produk tersebut.

Sebagai salah satu negara kepulauan terbesar di dunia dengan lebih dari 17.000 pulau dengan kondisi alam yang unik dan beragam serta memiliki potensi besar untuk mengembangkan produk berkualitas tinggi yang dikombinasikan dengan keterampilan serta faktor sosial dan budaya, namun sangat disayangkan bahwa disamping fakta tersebut, Indonesia masih berjuang keras untuk membentuk kerangka ekonomi berbasis kreativitas dan kolektivitas lokal sebagai pilar ekonomi kerakyatan yang menghasilkan keuntungan signifikan. Hal tersebut salah satunya dibuktikan oleh hasil riset dari Jeffrey Neilson, peneliti kopi Indonesia dari Sydney University yang meneliti 2 (dua) pusat produksi kopi dengan IG yaitu Kintamani di Bali dan Kopi Bajawa di Flores (Nusa Tenggara Timur), melalui penelitian yang dilakukan dalam rentang waktu 16 (enam belas) tahun, terdapat fakta yang sangat ironis dari kesimpulan riset tersebut. Pertama, belum terdapat tanda terjadinya peningkatan harga kopi akibat penggunaan IG Kopi Indonesia. Kedua, IG belum secara efektif digunakan sebagai tanda mutu di pasar karena belum dicari oleh pembeli. Terkait dengan indikator keberhasilan / efektivitas IG baru dapat dikatakan berhasil ketika petani sudah mendapatkan sertifikasi sebagai produk indikasi geografis terdaftar dan IG di lokasi - lokasi produsen produk sudah berhasil melindungi warisan budaya (Muhajir 2018).

Sebagai suatu rezim kekayaan intelektual yang bercorak kolektif, IG bertujuan untuk membantu individu, produsen, pelaku usaha manufaktur dan komunitas untuk mengidentifikasi, melindungi sekaligus memperoleh hasil yang bermanfaat berupa keuntungan dari produksi produk IG, namun perlu diingat bahwa pembangunan berkelanjutan terhadap produk - produk IG membutuhkan suatu collective action yang harus didukung oleh pilar - pilar terkait dalam memfasilitasi eksplorasi komersial yang berkesinambungan untuk produk lokal dan pada saat yang sama menuntut produsen produk untuk mempertahankan kualitas 
dan karakteristik produk agar tetap dapat memenuhi kriteria perlindungan Indikasi Geografis.

Fungsi Indikasi Geografis pada suatu produk utamanya terkait 3 (tiga) aspek vital dari identitas produk yaitu: asal suatu produk, kualitas produk tersebut serta pengaruh faktor geografis dan faktor keahlian / keterampilan manusia dalam menciptakan produk yang berkualitas (Almusawir 2013). Alasan utama adalah karena potensi ekonomi dari produk - produk IG secara global tidak terbantahkan, di Perancis terdapat lebih dari 732 produk yang terdaftar dengan Indikasi Asal (Appellations of Origin - AO) dan Indikasi Geografis (Geographical Indication - GI) pada tahun 2016 (INAO, n.d.) selain itu IG mempunyai peran penting bagi suatu bangsa, karena dapat dimanfaatkan sebagai sumber penghidupan dan kesempatan untuk meningkatkan taraf hidup terutama dalam lingkup regional / daerah. Perlindungan IG yang kuat dapat membantu petani lokal untuk mendapatkan penghasilan yang lebih baik dan membuka lapangan pekerjaan dan sumber penciptaan kekayaan bagi masyarakat lokal, sebagai contoh ekspor Teh Ceylon di Sri Lanka yang dapat menghasilkan penghasilan tahunan sebesar Rp. 1,5 milyar USD, dimana nilai tersebut sanggup menyaingi seluruh nilai ekspor makanan nasional per tahun, berkontribusi sebesar $2 \%$ Gross Domestic Product dengan serapan tenaga kerja yang mencapai $10 \%$ (sepuluh persen) populasi Sri Lanka, peranan industri Teh Ceylon sangat vital bagi ekonomi Sri Lanka.

Berdasarkan latar belakang yang telah diuraikan diatas, artikel ini bermaksud menyajikan analisis sekaligus memberikan gagasan kritis konseptual mengenai pemanfaatan Indikasi Geografis sebagai bagian dari kekayaan intelektual yang telah menjadi sebuah rezim perlindungan produk yang berakar pada lokalitas namun telah secara luas diterima dalam skala internasional yang memiliki potensi untuk berperan sebagai instrumen trickle - down effect sekaligus bottom up economic development dalam kerangka sharing economy di era disrupsi digital yang menyediakan platform yang sangat efektif dalam mendorong pertumbuhan sharing economy menuju collaborative economy. 


\section{PEMBAHASAN}

\section{A. Disrupsi Digital dan Konsep Sharing Economy di Indonesia}

Istilah "Disrupsi" menjadi popular setelah Clayton M. Christensen, seorang guru besar Harvard Business School menulis buku berjudul The Innovator Dilemma pada tahun 1997 yang menyatakan bahwa:

"The concept of disruption is about competitive response, it is not a theory of growth, it's adjacent to growth, but it's not about growth"

Disrupsi bukan hanya sebuah perubahan, namun lebih merupakan suatu inovasi yang menyebabkan pergantian tatanan dimana sistem atau cara - cara lama akan digantikan dengan cara - cara baru. Mengacu pada pendapat Clayton M Christensen, disrupsi tidak selalu mengenai pertumbuhan, tetapi lebih kepada inovasi yang sangat progresif dimana suatu perusahaan / pelaku usaha harus terus menerus berkompetisi untuk merespon perubahan tersebut melalui inovasi yang berkesinambungan (sustaining innovation).

Peter Diamandis, Co Founder Singularity University meramalkan bahwa sustainable innovation akan membawa manusia secara bertahap ke era keberlimpahan (abundance era) dimana perekonomian akan berjalan melalui mode free / sharing economy. Tahap pertama menuju abundance era adalah transformnasi digital (digitalization) yang mengantar dunia pada era revolusi industri 4.0 dimana terjadi shifting trend / peralihan kecenderungan ke electronic commerce (e-commerce), Internet of Things (IoT), Artificial Intelligence (AI) sehingga banyak yang mengidentikan era Revolusi Industri 4.0 sebagai era Disrupsi Digital.

Disrupsi digital menyediakan platform yang sangat efektif dalam mendorong pertumbuhan sharing economy melalui 3 (tiga) pilar yaitu economic sharing, trust sharing dan intellectual sharing. Konsep sharing economy yang utamanya bertujuan untuk efisiensi sumber daya (resources), 
meminimalisir dan mendistribusi risiko bagi para stakeholders menjadi konsep yang sangat "menggema" di dunia bisnis global di era ekonomi kreatif berbasis teknologi digital. Sharing economy sangat efektif dalam menekan beban permodalan dan menjadi platform yang dapat menghimpun aset permodalan secara efektif dan mendukung aktivitas bisnis. Agar dapat memberikan kontribusi secara maksimal, konsep sharing economy perlu didukung dan disempurnakan menjadi konsep cooperative economy yang dapat berperan sebagai instrumen trickle - down effect (Aghnion and Patrick Bolton 1997) sekaligus bottom up economic development. Kedua peran ini terbukti gagal dilaksanakan oleh venture capitalist yang cenderung lebih menciptakan konglomerasi karena belum mampu secara efektif melakukan redistribusi ekonomi yang akhirnya menyebabkan melebarnya jurang ketimpangan dan kesenjangan ekonomi.

Sharing economy yang diimplementasikan melalui economic gardening (Barrios and Barrios 2004) merupakan penerapan yang lebih luas dari konsep sustainable development yang secara sederhana dapat diartikan sebagai pembangunan yang dilakukan untuk memenuhi kebutuhan generasi saat ini tanpa mengorbankan kemampuan generasi yang akan datang untuk memenuhi kebutuhannya, dimana ketika sumber daya pembangunan ekonomi dikerahkan untuk mendukung bisnis lokal, maka hal tersebut akan menumbuhkan kewirausahaan lokal (local entrepreneurship) yang dapat mengarah kepada diversifikasi kegiatan ekonomi masyarakat yang pada akhirnya dapat melindungi ekonomi lokal agar tidak terlalu tergantung kepada industri tertentu dengan memicu tumbuhnya self employment dan local entrepreneurship.

Local entrepreneurship juga menghasilkan economic multiplier effects diantaranya berupa kenaikan intensitas alur produk barang dan jasa, munculnya inovasi - inovasi dalam lingkup lokal yang dapat menjaga stabilitas perekonomian lokal dan yang paling penting dapat mendorong pembangunan 
berkelanjutan dan kemandirian ekonomi dalam kerangka holistik yang memandang manusia dan lingkungan bukan sebagai entitas yang terpisah, tetapi sebagai bagian dari rantai kehidupan yang saling tergantung dan saling terhubung satu sama lain. Pada intinya yang menjadi tujuan dari sustainable development adalah pertumbuhan ekonomi (economic growth), stabilitas sosial (social stability) dan keamanan lingkungan (Penker 2007)

Sharing economy juga merupakan jawaban yang efektif dan solutif terhadap keterbatasan modal bagi usaha - usaha rintisan yang marak berkembang di masyarakat dalam bentuk home industries dan informal business di level usaha mikro, usaha kecil dan menengah, sebuah sektor usaha yang terbukti memiliki andil cukup besar dalam pembangunan dan pemerataan ekonomi serta merupakan usaha yang memiliki ketahanan tinggi (resilient) bahkan terhadap krisis ekonomi global ketika perusahaan dan industri besar banyak yang mengalami kemunduran bahkan kebangkrutan. Sharing economy yang mampu diimplementasikan melalui cooperative economy akan sangat efektif dalam membentuk kemitraan, efektivitas dan efisiensi penggunaan sumber daya dan pemerataan distribusi hasil ekonomi yang pada akhirnya mampu mengelaborasi pengembangan ekonomi masyarakat menuju kemandirian.

\section{B. Implementasi Konsep Sharing Economy Dalam Pemanfaatan Indikasi Geografis Di Era Ekonomi Digital}

Produk ekonomi kreatif banyak berakar dari pemberdayaan masyarakat secara kolektif (collective community development) melalui pemanfaatan sumber daya (resources) yang ada di daerah untuk penciptaan produk asli daerah yang memiliki karakteristik dan identitas unik yang memberikan keuntungan kompetitif (competitive advantage) dari produk tersebut disebabkan kecenderungan tingkah laku konsumen yang menunjukkan 
kesediaan untuk membayar harga lebih tinggi bagi produk asli / produk khas suatu daerah (WIPO 2004) yang memiliki karakteristik yang berkorelasi dengan asal usul geografisnya. Sebuah survey di Uni Eropa menggambarkan bahwa sejak tahun 2003, sebanyak $40 \%$ konsumen bersedia membayar lebih tinggi diatas harga produk premium untuk produk IG, sebuah studi juga menunjukkan bahwa produk IG memiliki nilai jual lebih baik di pasaran dibandingkan dengan produk non IG dengan value premium rate sebesar 2,23 hal ini berarti produk IG terjual 2,23 kali lebih tinggi dibandingkan produk non IG dengan kualitas yang sama (Chever 2012). Di Indonesia, Indikasi Geografis sebagai suatu tanda yang menunjukkan daerah asal suatu barang dan I atau produk yang karena faktor lingkungan geografis termasuk faktor alam, faktor manusia atau kombinasi dari kedua faktor tersebut memberikan reputasi, kualitas dan karakteristik tertentu pada barang dan / atau produk yang dihasilkan ditempatkan bersama dengan perlindungan Merek pada dalam Undang - Undang Nomor 20 Tahun 2016 tentang Merek dan Indikasi Geografis.

IG yang dapat diterapkan pada produk sumber daya alam, barang kerajinan maupun hasil industri merupakan instrumen vital bagi Indonesia yang memiliki kekayaan alam dan kekayaan budaya yang sangat beraneka ragam dilengkapi dengan local wisdom dan pengetahuan tradisional dalam menghasilkan produk yang berasal dari kombinasi faktor alam (geografis) dan faktor manusia. IG melindungi keterkaitan historis antara suatu produk dengan tempat produk tersebut berasal dan diproduksi serta masyarakat yang memproduksi produk tersebut, IG berakar pada lokalitas, namun dalam perkembangannya IG berada pada persimpangan 2 (dua) isu internasional yaitu kompetisi perdagangan global dan kekayaan intelektual. IG dirancang sebagai penghargaan dan upaya perlindungan bagi kreativitas, penciptaan kualitas dan reputasi oleh masyarakat selama bertahun - tahun bahkan lintas generasi dalam upaya membangun dan mempertahankan kualitas dan standar 
tradisional yang tinggi dipadukan dengan inovasi dan pengembangan produk sehingga IG menjadi jaminan kualitas, reputasi dan orisinalitas bagi produk lokal yang berdaya saing global (Port 2015).

Label IG pada suatu produk merupakan keunggulan kompetitif yang memiliki pengaruh signifikan dalam perdagangan internasional karena dapat menjalankan berbagai fungsi dari mulai jaminan keaslian produk, jaminan standar kualitas produk hingga sarana promosi yang telah lama dipraktikan secara kolektif terhadap wine and liquor seperti Scocth, Champagne dan Cognac di Eropa. Produk makanan juga telah mendapatkan perlindungan sejak tahun 1992 melalui Protected Geographical Indication (PGI) dan Protected Designation of Origin (PDO). Berkaca pada fakta bahwa produk - produk tersebut memiliki posisi yang sangat baik dipasaran sebagai produk premium dengan tingkat consumer recognition dan consumer loyalty yang tinggi, Uni Eropa sangat agresif dalam perlindungan IG, hal serupa juga terjadi di Amerika Serikat dimana beberapa produsen produk domestik telah membangun IG yang selaras dengan regional branding pada produk mereka seperti Wisconsin Cheese, Idaho Potato, Florida Orange dan Kona Coffee (Babcock and Babcock 2015). Dalam lingkup Indonesia, IG terbukti mampu meningkatkan harga kopi specialty dari daerah tertentu, sebagai contoh Kopi Gayo yang dalam kurun waktu 6 (enam) tahun terdaftar sebagai produk IG mengalami kenaikan harga untuk roasted bean dari Rp.60.000,- (enam puluh ribu rupiah) menjadi Rp. 200.000,- (dua ratus ribu rupiah) (Muhajir 2018).

Perlindungan Indikasi Geografis menyediakan platform bagi collective product branding dan joint marketing yang sangat krusial bagi business sustainability karena memiliki double impact terhadap produk maupun terhadap pelaku usaha. Produk Indikasi Geografis dapat lebih terjaga kualitasnya karena dalam penggunaan Indikasi Geografis, pelaku usaha harus menjamin adanya standardisasi mutu produk dan memastikan standar kualitas tersebut tetap terjaga baik mengenai sifat, ciri dan mutu produk. Bagi pelaku usaha, Indikasi 
Geografis merupakan sarana dalam distribusi sharing capital yang sangat efisien terkait biaya pendaftaran, biaya pemasaran dan biaya pemeliharaan (maintenance) yang dapat ditanggung bersama sehingga akan lebih terjangkau. Pendaftaran Indikasi Geografis membawa konsekuensi praktis berupa pelaksanaan joint marketing antar pelaku usaha yang memproduksi produk sejenis hingga pemasaran produk tersebut dapat lebih memiliki jangkauan luas agar produk dapat mencapai product recognition dan consumer loyalty melalui promosi serta pemasaran produk yang lebih luas.

Pengarusutamaan kolektivitas (collectivity mainstreaming) dalam perlindungan Indikasi Geografis memberikan manfaat kepada petani kecil maupun pengrajin lokal (local artisans) yang umumnya belum memiliki sumber daya dan sarana pemasaran produk yang memadai. Ketika reputasi produk IG telah dimiliki dan telah dikenal di pasaran, maka stake holders lokal akan memperoleh manfaat berupa pangsa pasar (niche market) hal ini menunjukan pentingnya mendorong kerjasama (cooperation) antara pemerintah dengan pelaku usaha agar perlindungan produk IG dapat diimplementasikan secara komprehensif dan dapat menimbulkan trickle - down effect sekaligus bottom up economic development.

Terdapat beberapa hal penting yang harus dipahami terkait perlindungan dan pengembangan Indikasi Geografis dalam konteks sharing economy, Pertama Indikasi Geografis merupakan aset yang memiliki nilai ekonomis (economic value) yang memberikan hak kebendaan (property rights) dan dapat menghasilkan keuntungan ekonomi (generate economic benefit) dari penggunaan dan pemanfaatannya. Kedua, Indikasi Geografis merupakan identitas produk sekaligus instrumen identifikasi yang dapat menunjukkan korelasi produk tersebut dengan kolektivitas dibalik produk tersebut. Ketiga, Indikasi Geografis merupakan strategi bisnis yang efektif di era disrupsi digital disaat banyak peran otot dan otak manusia digantikan oleh teknologi, Indikasi Geografis memberikan value added pada produk yang dihasilkan dari advanced 
approach dimana manusia sebagai pelaku usaha fokus pada aspek - aspek yang sifatnya kreatif, historis dan geografis misalnya dengan membangun nilai dan image produk yang terkoneksi dengan personalitas dan personal taste dari konsumen.

Untuk dapat mengimplementasikan secara komprehensif ketiga fungsi IG tersebut, perlu dilakukan langkah - langkah strategis yang sesuai dengan karakteristik IG sebagai KI yang berdimensi kolektif, yaitu melalui rangkaian tahap collective action dengan pendekatan kelembagaan. Tahap pertama adalah dukungan dalam inventarisasi produk yang memiliki potensi untuk didaftarkan sebagai IG melalui sosialisasi dan upaya yang lebih gencar dalam menemukan potensi IG di setiap daerah dan dukungan serta pendampingan dalam penyusunan Dokumen Deskripsi Indikasi Geografis sebagai suatu dokumen yang memuat informasi, termasuk reputasi, kualitas, dan karakteristik barang dan / atau produk yang terkait dengan faktor geografis dari barang dan / atau produk yang dimohonkan Indikasi Geografisnya (Indonesia, n.d.) sebagai bagian utama dari persyaratan pendaftaran IG. Dalam ketentuan mengenai Peraturan Pemerintah Tentang Indikasi Geografis, kelengkapan persyaratan permohonan IG harus dilengkapi persyaratan - persyaratan yang penyusunannya membutuhkan waktu, biaya, tenaga dan riset yang mendalam sehingga dukungan dan pendampingan sangat dibutuhkan dalam hal ini. Menurut ketentuan Pasal 6 ayat (3) Peraturan Pemerintah Republik Indonesia No. 51 Tahun 2007 tentang Indikasi Geografis, Permohonan harus dilengkapi persyaratan yang terdiri atas :

a. Nama Indikasi Geografis yang dimohonkan pendaftarannya;

b. Nama barang yang dilindungi oleh Indikasi Geografis;

c. Uraian mengenai karakteristik dan kualitas yang membedakan barang tertentu dengan barang lain yang memiliki kategori sama dan menjelaskan tentang hubungannya dengan daerah tempat barang tersebut dihasilkan; 
d. Uraian mengenai lingkungan geografis serta faktor alam dan faktor manusia yang merupakan satu kesatuan dalam memberikan pengaruh terhadap kualitas atau karakteristik dari barang yang dihasilkan;

e. Uraian tentang batas - batas daerah dan / atau peta wilayah yang dicakup oleh indikasi geografis;

f. Uraian mengenai sejarah dan tradisi yang berhubungan dengan pemakaian Indikasi Geografis untuk menandai barang yang dihasilkan di daerah tersebut, termasuk pengakuan dari masyarakat mengenai Indikasi Geografis tersebut;

g. Uraian yang menjelaskan tentang proses produksi, proses pengolahan dan proses pembuatan yang digunakan sehingga memungkinkan setiap produsen di daerah tersebut untuk memproduksi, mengolah atau membuat barang terkait;

h. Uraian mengenai metode yang digunakan untuk menguji kualitas barang yang dihasilkan; dan

i. Label yang digunakan pada barang dan memuat Indikasi Geografis.

Langkah selanjutnya adalah formulasi dan pendirian lembaga. Di setiap daerah dengan produk IG umumnya didaftarkan oleh MPIG (Masyarakat Perlindungan Indikasi Geografis). Perlu dilakukan penguatan MPIG selaku produsen barang yang dilindungi rezim IG sangat krusial, misalnya dibentuk secara legal melalui Keputusan Kepala Daerah setempat atau dengan Akta Notaris (Directorate General of Intellectual Property 2018). Hal berikutnya yang juga penting adalah mengenai koordinasi antar lembaga terkait yang bersifat partisipatoris dalam pengembangan produk IG antara lain untuk menyatukan pelaku usaha dalam rantai nilai (value chain) yang produktif, melakukan pengawasan dan pengelolaan IG terkait kontrol kualitas dan kendali mutu barang antara masyarakat, pemerintah daerah, pemerintah pusat dan Kantor Wilayah Kementerian Hukum dan HAM setempat mulai dari tahap 
persiapan untuk pemenuhan persyaratan permohonan IG, mengajukan permohonan pendaftaran IG, pemanfaatan dan komersialisasi IG, sosialisasi perlindungan IG kepada masyarakat, pemetaan dan inventarisasi potensi produk IG, pelatihan dan pendampingan, pemantauan, evaluasi dan pembinaan, memberikan perlindungan hukum dan memfasilitasi pengembangan, pengolahan dan pemasaran barang dan / atau produk IG.

Koordinasi dan sinkronisasi pada level kementerian juga telah digulirkan melalui program One Product One Village yang diluncurkan oleh Kementerian Perindustrian dengan tujuan mendorong penelitian, inventarisisasi dan kemunculan produk - produk khas / asli daerah yang banyak menyimpan potensi Indikasi Geografis. Koordinasi yang sifatnya eksternal dimulai dari tahapan promosi produk IG dan upaya - upaya membuka akses pasar atau bahkan menciptakan pasar sendiri untuk produk - produk IG. Di era disrupsi digital, proses penciptaan akses pasar telah disederhanakan melalui dukungan teknologi digital. Platform e - commerce menyediakan keterbukaan terhadap akses pasar dan merupakan sarana pemasaran yang efektif, cepat dengan jangkauan luas dan biaya ringan.

Sebagai suatu Kekayaan Intelektual, IG memiliki aspek hak yang melekat padanya yaitu Hak Ekonomi (disamping Hak Moral) yakni hak untuk memperoleh keuntungan ekonomi dari pemanfaatan kekayaan intelektual tersebut. Terkait dengan produk IG yang memiliki korelasi yang sangat kuat dengan daerah geografisnya, potensi ekonomi yang dihasilkan dapat membentuk trickle down effect dan bottom up economic development. Reputasi produk IG sebagai produk yang berkualitas dapat membuka akses pasar bahkan menciptakan pasar yang baru. Hal ini akan berdampak langsung maupun tidak langsung terhadap masyarakat dan kawasan penghasil produk IG seperti misalnya sebagai sumber pendapatan (income source), membuka lapangan pekerjaan (generators of job), pengentasan kemiskinan (poverty eradication), pemberdayaan masyarakat (society upgrading / community development) serta 
dapat berfungsi sebagai sarana promosi wisata kawasan melalui pembentukan regional branding.

Manfaat dari pemanfaatan IG melalui konsep sharing economy hanya bisa optimal ketika mendapatkan dukungan dari pemerintah daerah dan pemerintah pusat misalnya dengan menginisiasi berbagai macam kebijakan untuk mempromosikan bisnis lokal agar dapat tumbuh, berkembang dan memberikan dampak positif terhadap pendapatan per kapita nasional melalui peningkatan ekonomi kawasan (regional economic development) (Rupasingha 2013).

\section{SIMPULAN DAN SARAN}

\section{A. Simpulan}

Produk Indikasi Geografis (IG) memiliki korelasi yang sangat kuat dengan daerah geografisnya, potensi ekonomi yang dihasilkan dapat membentuk trickle down effect dan bottom up economic development. Reputasi produk IG sebagai produk yang berkualitas dapat membuka akses pasar bahkan menciptakan pasar yang baru. Hal ini akan berdampak langsung maupun tidak langsung terhadap masyarakat dan kawasan penghasil produk IG sebagai sumber pendapatan (income source), membuka lapangan pekerjaan (job vacancy), pengentasan kemiskinan (poverty eradication), pemberdayaan masyarakat (society upgrading / community development) serta dapat berfungsi sebagai sarana promosi wisata kawasan dengan pembentukan regional branding melalui konsep sharing economy yang memiliki banyak keunggulan kompetitif sebagai suatu model ekonomi yang bekerja melalui proses kolaborasi aset, ide dan kreativitas dari sekumpulan orang dengan efektif dan efisien serta dapat memitigasi pengelolaan risiko dalam penciptaan dan pemasaran produk dan menghasilkan pendapatan (generate income) yang kemudian akan 
didistribusikan kembali kepada para kolaborator dalam sebuah collaborative platform.

\section{B. Saran}

Indonesia perlu mengambil inisiatif terkait konsep sharing economy yang telah menjadi fenomena global mengingat konsep sharing economy memiliki posibilitas kesesuaian kuat dengan dengan prinsip ekonomi Indonesia yaitu gotong royong (cooperative) dan kekeluargaan (kinship) yang akan sangat mudah dan efektif diterima oleh masyarakat. Penelitian dan inventarisasi potensi produk indikasi geografis perlu menjadi prioritas dalam program ekonomi kerakyatan. Tindak lanjut dari hasil inventaris tersebut harus dilaksanakan melalui collective action mulai dari segi inisiasi, regulasi dan tataran implementasi. Pemanfaatan Indikasi Geografis melalui konsep sharing economy yang diimplementasikan melalui collective action harus diinisiasi agar dapat membentuk collaborative economy dalam platform ekonomi kerakyatan dengan memanfaatkan teknologi informasi di era ekonomi digital sebagai sarana edukasi publik sekaligus sarana promosi bagi produk Indikasi Geografis. 


\section{DAFTAR PUSTAKA}

Aghnion, Philippe, and Patrick Bolton. 1997. "A Theory of Trickle - Down Growth and Development." Review of Economic Studies 64. https://www.researchgate.net/ publication/4783221_A_Theory_of_TrickleDown_Growth_and_Development.

Alfons, Maria. 2017. "Implementasi Hak Kekayaan Intelektual Dalam Perspektif Negara Hukum." Jurnal Legislasi Indonesia 14 (3).

Almusawir. 2013. "LEGAL INSTRUMENT FOR PROTECTION OF GEOGRAPHICAL INDICATION PRODUCT IN INDONESIA Almusawir." Journal of Humanity 1 (1). http://www.hgpub.com/index_files/jhi/jhipdf/jhi.22317252.2013.0302.8794.10.pdf.

Athanassiou, Ersi, and Agapi Kotsi. 2019. "Sharing Economy - Collaborative Economy: Use of Services in Greece." Greek Economic Outlook, no. 38. https://www.researchgate.net/publication/332144869 Sharing Economy - Collaborative_economy_Use_of_services_in_Greece.

Babcock, Bruce A, and Bruce A Babcock. 2015. "Geographical Indications, Property Rights, and Value-Added Agriculture." lowa Ag Review 9 (4).

Barrios, Sharon, and David Barrios. 2004. "Reconsidering Economic Development: The Prospect for Economic Gardening." Public Administration Quarterly 28 (1).

Chever, Tanguy. 2012. "Value of Production of Agricultural Products and Foodstuffs, Wine, Aromatised Wines and Spirits Protected by a Geographical Indication (GI)." Agriculture Nutrition Development. http://ec.europa.eu/ agriculture/sites/agriculture/files/external-studies/2012/ value-gi/finalreport en.pdf.

Damian, Eddy. 2014. Hukum Hak Cipta. Keempat. Bandung: Alumni.

Demary, Vera. 2015. "Competition in the Sharing Economy." Cologne Institute for Economic Research.

Directorate General of Intellectual Property, Ministry of Law and Human Rights Republic of Indonesia. 2018. Modul Pelatihan Indikasi Geografis. Indonesian

- Swiss Intellectual Property Project (ISIP),. 
Horton, John ], and Richard ] Zeckhauser. 2016. OWNING, USING AND RENTING: SOME SIMPLE ECONOMICS OF THE "SHARING ECONOMY." http://www.nber.org/papers/w22029\%0Ahttp://www.nber.org/papers/ w22029\%0Ahttp://www.nber.org/papers/w22029.

INAO. n.d. "INAO." https://www.inao.gouv.fr/Publications/Donnees-etcartes/Informations-economiques.

Indonesia, Republik. n.d. "Undang - Undang Republik Indonesia Nomor 20 Tahun 2016 Tentang Merek Dan Indikasi Geografis."

Muhajir, Anton. 2018. "Indikasi Geografis Belum Berdampak Pada Petani Kopi, Benarkah?” Mongabay. 2018. https://www.mongabay.co.id/ 2018/05/02/indikasi-geografis-belum-berdampak-pada-petani-kopibenarkah/.

Penker, Marianne. 2007. "Do Geographical Indications Promote Sustainable Rural Development." Lincoln University. https://www.researchgate.net/publication/

237547703_Do_geographical_indications_promote_sustainable_rural_de velopment.

Port, Kenneth L. 2015. “Regionally Based Collective Trademark System in Japan : Geographical Indications by a Different Name or a Political Misdirection, Cybaris: An Intellectual Property Law Review." Cybaris: An Intellectual Property Law Review 6 (2).

Roszak, Theodore. 1969. The Making of A Counter Culture. Doubleday \& Company.

Rupasingha, Anil. 2013. "Locally Owned: Do Local Business Ownership and Size Matter for Local Economic Well-Being?" Federal Reserve Bank of Atlanta, no. 2013-01. https://doi.org/DOI:

Sudaryat, Sudjana, and Rika Ratna Permata. 2010. Hak Kekayaan Inteletual-Memahami Prinsip Dasar, Cakupan Dan Undang-Undang Yang Berlaku. Bandung: Oase Media.

WIPO. 1883. Paris Convention for the Protection of Industrial Property.

- - . 2004. Geographical Indications: An Introduction, WIPO Intellectual Property Handbook. 